MERCADOLOGIA

\title{
CONSUMER FINANCIAL SACRIFICE: PROPOSING A SCALE
}

\author{
SACRIFÍCIO FINANCEIRO DO CONSUMIDOR: PROPOSIÇÃO DE UMA ESCALA
}

Jairo de Pontes Gomes

Universidade Federal de Pernambuco

Salomão Alencar de Farias

Universidade Federal de Pernambuco

Marianny Jessica de Brito Silva

Universidade Federal de Pernambuco

Francisco Vicente Sales Melo

Universidade Federal de Pernambuco
Polyana de Lourdes Saraiva do Nascimento Universidade Federal de Pernambuco
Data de submissão: 20 dez. 20 17. Data de aprovação:

17 abr. 2018 . Sistema de avaliação: Double blind review. Universidade FUMEC / FACE. Prof. Dr. Henrique Cordeiro Martins. Prof. Dr. Cid Gonçalves Filho.

\section{ABSTRACT}

In the Marketing field, although the term sacrifice has usually been associated with the perceived value, studies about the 'financial sacrifice' for the purchase are still incipient. Through a literature review, it was possible to identify gaps both for measurement and for an adequate definition of this construct in the consumer behavior perspective. So, this article aims to develop a scale to measure the financial sacrifice for purchase, showing the concept of financial sacrifice as an act or the willingness to give up something valued, aiming the acquisition of something else of greater value. From this, the Consumer Financial Sacrifice - CFS scale was developed following the steps proposed by Churchill (1979). The results indicated that the proposed scale has good levels of reliability and validity, being single dimensional, formed by three items, contributing to highlight that the financial sacrifice can generate both negative and positive aspects for the consumer.

\section{KEYWORDS}

Marketing. Consumer Behavior. Financial Sacrifice. Purchase. Development of the Scale. 


\section{RESUMO}

No campo do Marketing, embora o termo sacrificio tenha sido associado ao valor percebido, os estudos sobre o "sacrificio financeiro" para a compra de um produto ainda são incipientes. Por meio de revisão da literatura, foram identificadas lacunas tanto para a medição quanto para uma definição adequada deste construto na perspectiva do comportamento do consumidor. Assim, este artigo objetivou desenvolver uma escala para medir o sacrificio financeiro para a compra, apresentando o conceito de que o sacrificio financeiro é o ato ou vontade de renunciar a algo valorizado, visando a aquisição de algo de maior valor. A partir disto, a escala Consumer Financial Sacrifice - CFS foi desenvolvida seguindo as etapas propostas por Churchill (1979). Os resultados indicaram que ela tem bons níveis de confiabilidade e validade, sendo unidimensional, formada por três itens, contribuindo para a conclusão de que o sacrificio financeiro pode gerar aspectos negativos e positivos para o consumidor.

\section{PALAVRAS-CHAVE}

Marketing. Comportamento do consumidor. Sacrificio financeiro. Compra. Desenvolvimento de Escala.

\section{INTRODUCTION}

Sacrifice is a construct specially explored in studies in the fields of anthropology, history and religion. Its meaning is complex because it implies a diversity of experiences related to the sacred, to give up something, to offer or to consecrate something or someone, among different things. In general, the act of sacrificing involves an element of suffering and moral transformation for those who perform it and/or for the sacrificed object or individual.

In the marketing field, sacrifice begins to be of interest of researchers at the end of the 1980s. From the study by Belk, Wallendorf and Sherry (1989), this construct was described as one of the possible characteristics and manifestations of the sacred. The authors turn to the understanding of the (des) sacralization processes inherent in consumer behavior. From this research, cul- tural aspects related to sacred, spiritual and religious consumption began to permeate the area's research (BELK;TUMBAT, 2005).

But it is not only in this religious sphere of consumption that it is possible to observe sacrificial practices. In general, sacrifice, as revealed by Shilling and Mellor (20I3), can be perceived in three ways: a) as expenditure/cost/expense, considering that this expenditure is a producer of the sacred phenomenon (BATAILLE, 1989); b) as 'scapegoat' in a community (GIRARD, 1995), and c) as a transcendent exchange, when individuals give up/give away something of themselves or objects they possess in exchanges that are transcendental rather than merely utilitarian (SIMMEL, 1990). From this, it can be seen the three forms of sacrifice, to a greater or lesser extent, are acts of consumption in which something or someone is consumed, in a way that they 
are possible opportunities for research in the field of consumer behavior.

In the consumption perspective, the study of sacrifice is still justified by the very popularization of the term among the individuals of contemporary society. It is not difficult to find in the discursive manifestations of consumers the word in question when they want to refer to some kind of effort to achieve something. The sacrifice in (not) acquiring and (not) using a given product is part of the current vocabulary, permeated by financial and identity crises. Therefore, the analyzed construct encompasses and impacts the atmosphere of consumption, as well as the way in which a person behaves in it.

Some studies that indirectly adopt Bataille's (1989) expenditure perception to describe sacrifice can be observed, turning to the elements of cost and expense related to the purchase of a product. Liljander and Strandvik (1995), for example, understand the sacrifice made by the client to acquire a good or service as the cost and price effort, so that from this is valued product satisfaction. The purchase intention, therefore, is affected by this monetary sacrifice perceived by the consumer (FONG et al., 20I5).

Even with a certain evolution in the field represented especially in the form of sacrifice as cost, research in the area of Marketing that approaches the sacrificial aspects in the consumption is still in need, especially when it is verified the popularization of the term in the social environment, used in a colloquial way. Most of the times, this construct is portrayed as a component of perceived value (e.g. DODDS; MONROE, 1985; FLINT; WOODRUFF; GARDIAL, 1997; LAPIERRE, 2000; TEAS; AGARWAL,
2000; WOODALL, 2003; LIN; WU; CHUANG; KAO, 2007) rather than as an isolated element that has a direct influence on consumer behavior. In addition, the measurement of the sacrifice still presents itself as a gap in the area. In a survey conducted on ACR website (Association for Consumer Research), in July 2017, no results were identified using the terms "financial sacrifice scale". Using the same search procedure in the ProQuest database, no documents with the terms analyzed were identified. In Brazil, with the terms of the search was not manuscript identified in a Spell-database search with these terms. The lack of results in the searches performed is presented as a gap in the area, since the measurement implies the possibility of describing and accessing data to understand a certain phenomenon of interest. Therefore, it is understood the importance of the construction of measurement scales that are bases of sustentation for the development of the sciences (CHURCHILL, 1979).

Aiming to fill the gap described previously, this study searches to develop a scale for sacrifice in consumption from the perspective of expense related to the purchase of a product (financial sacrifice) proposed by Bataille (1989). Among consumer activities, buying is understood as a crucial element in the sacrificial perspective. Consumer decision-making involves analyzing the costs of buying or not buying a given product perceived by this individual. Such process is critical to understand consumer behavior and develop the composite marketing planning (ENGEL; BLACKWELL; MINIARD, 1995). Therefore, the proposed scale turns to the buying process. It is important to emphasize that, although sacrifice can contemplate different dimensions, this manuscript focused 
only on the financial dimension, since it has a direct impact on the consumer purchase decision process. With this objective, it is sought to establish a base of support of the sacrifice in the Marketing area, collaborating with the increase of the production of international and national research focused on this theme.

To this end, this paper is divided as follows: in addition to the introduction, a section on sacrifice in the financial perspective is developed, followed by the elements of scale construction. Final considerations are pointed out at the end of the study.

\section{The sacrifice and its financial perspective}

Sacrifice means "to make sacred". That comes from the Latin word sacrificere, a junction of the terms sacer (sacred) and facere (do) (BADJE, 2005). Initially, its conceptualization was associated with religious issues and the search for a change from a person or object of the profane domain to the transcendent domain and worship of God (MATEUS, 2008). For Belk, Wallendorf and Sherry Jr. (1989), the individual gives up something important, in order to establish a contact with the sacred. In this perspective, sacrifice prepares the individual for a communion with the sacred experience, reinforcing the extraordinary character that it possesses.

In consumption, sacrifice may involve monetary or non-monetary elements (DODDS; MONROE; GREWAL, 199I; LAPIERRE, 2000). For example, perceived benefits and sacrifices can be built from the intrinsic and extrinsic attributes of the product, including texture, quality, price, performance, service, and brand (ZEITHAML, 1988). In particular, as Fong et al. (20I5) highlight, most marketing literature points out that the purchase intention is affected by the perceived monetary sacrifice by the consumer.

Therefore, the study of sacrifice in consumption involves the perspective of value perception. This is an element associated with what the individual gives and receives in the purchase of a good or service. Some authors treat this theme with greater emphasis, such as: Zeithaml (1988) who developed an exploratory study to elaborate a conceptual model of the relationship between price, quality and value perceived by consumers: Dodds, Monroe and Grewal (I99I) studied the effect of price, brand, and store information on consumer perceptions of quality, value, and willingness to purchase the good or service. In addition, Caruana, Money and Berthon (2000) developed an exploratory research to understand if value acts as a moderator between quality of service and customer satisfaction. Lastly, by performing two experiments, Teas and Agarwal (2000) studied the relationship of extrinsic effects (price, brand name, store name and country of origin) in consumer perception of quality, sacrifice and value.

New studies emerged from these authors perspective, such as: Woodall (2003) who developed a dimensions of perceived value summary, and identified among these several types of sacrifice (including the monetary) linked to time consumption, Sumaedi, Bakti and Yarmen (2012) studied the relationship between consumer behavioral intentions and other latent factor (like satisfaction, perceived value, perceived sacrifice) and service quality, Chang (2013) who studied the processing motivation to price perception, by highlighting the influence of fluency 
on price-perceived quality, price-perceived monetary sacrifice or purchase intention, and Tseng (2016) who, in one of his experiments, analyzed the relationships among a green promotion setting, perceived nonmonetary and monetary sacrifice, and purchase intention toward the list price.

In this sense, the concept of consumer value is subdivided in two dimensions of behavior; they are: economic dimension, which involves the prices perceived in the transaction, and the psychological dimension, which encompasses the emotional and cognitive influence of the elements (CURRÁS et al., 2015). As in the perception of value, sacrifice in consumption also involves two dimensions, already described previously as monetary and non-monetary. In this perspective, Lapierre (2000) states that customer sacrifice is defined as the global monetary and non-monetary costs invested in completing a transaction or developing a relationship with a supplier.

This perception of value of the product means to compare the quality and benefits associated with the sacrifices related to the payment of the price requested for that good (MONROE, 1990). It is important to note that the price of a good, can provide several important information for the consumer. Thus, when assessed negatively, it represents an economic sacrifice (FONG et al., 20I5).

Based on the understanding of sacrifice, developed by the authors cited in this article, a conceptualization of financial sacrifice for purchase was established with the purpose of constructing and validating a measurement scale. In this perspective, the sacrifice of buying a product is defined as the act or the willingness to give up something valued, aiming at the acquisition of another.

\section{Scale Construction: Consumer Financial Sacrifice (CFS)}

With the purpose of proposing a scale to measure the financial sacrifice in the product acquisition, it was adopted the perspective of Churchill (1979), a classic proposal in the development of scales in the Marketing area. A review of the literature related to sacrifice in different fields was carried out, but with focus on marketing and consumer behavior. After that, it was started to develop the scale carefully following Churchill (1979) proposed steps, as follow.

\section{Step I: Construct domain specification}

The initial step consisted in the effort of defining the construct boundaries and analyzing its possible dimensionalities. According to Churchill (1979, p. 67) "It is imperative that researchers consult the literature when conceptualizing constructs and specifying domain". For this, a bibliographic research was carried out contemplating the main elements of the sacrifice construct. A total of 68 papers were evaluated in different areas of knowledge (anthropology, sociology, psychology, economics and marketing), from which it was possible to conceptualize the financial sacrifice for the purchase of a product, as previously presented. The main conceptions of the sacrifice found in the bibliographic research are shown in Table I.

In this research, considering the attributes of the construct, sacrifice was defined as a one-dimensional element (because it represents a general measure), a multiple reflexive type, and its measurement was performed by items that reflect the effects on the construct variation. 
TABLE 1 - Sacrifice Definitions

\begin{tabular}{|c|c|c|c|}
\hline Author & Year & Sacrifice Conception & Study Field \\
\hline Sykers & 1748 & $\begin{array}{l}\text { Whatever is given or offered in a Solemn manner immediately to God, 'so as } \\
\text { that Part of it or the Whole is consumed'. }\end{array}$ & Anthropology \\
\hline Smith & 1894 & $\begin{array}{l}\text { Communion between the god and his worshippers by joint participation in the } \\
\text { living flesh and blood of a sacred victim. }\end{array}$ & Anthropology \\
\hline Hubert \& Mauss & 1897 & $\begin{array}{l}\text { Sacrifice is a religious act which, through the consecration of a victim, mod- } \\
\text { ifies the condition of the moral person who accomplishes it or that of certain } \\
\text { objects with which he is concerned. }\end{array}$ & Anthropology \\
\hline Evans-Pritchard & 1956 & $\begin{array}{l}\text { A way of doing business between gods and men. A bargain is struck. There is } \\
\text { an exchange. }\end{array}$ & Anthropology \\
\hline Zeithaml & 1988 & Sacrifice as a component of price and quality perception. & Marketing \\
\hline Bataille & 1989 & $\begin{array}{l}\text { Sacrifice restores to sacred world that which servile use has degraded, ren- } \\
\text { dered profane. }\end{array}$ & Economics \\
\hline Monroe & 1990 & $\begin{array}{l}\text { The sacrifice is represented by the selling price and all subsequent costs to } \\
\text { the customer of acquiring, installing, maintaining, and using the product over } \\
\text { its useful life. }\end{array}$ & Marketing \\
\hline Simmel & 1990 & $\begin{array}{l}\text { The economic exchange - whether it is of objects of labor or labor power in- } \\
\text { vested in objects - always signifies the sacrifice of an otherwise useful good, } \\
\text { however much eudaemonistic gain is involved. }\end{array}$ & Economics \\
\hline Freud & 1996 & A form of renunciation of something that has value to the individual. & Psychology \\
\hline Van Lange et al. & 1997 & $\begin{array}{l}\text { The propensity to give up immediate self-interest to promote the well-being of } \\
\text { a partner or relationship. }\end{array}$ & Psychology \\
\hline Pine \& Gilmore & 2000 & $\begin{array}{l}\text { The customer sacrifice is the gap between what a customer settles for and } \\
\text { what he wants exactly. }\end{array}$ & Marketing \\
\hline Lapierre & 2000 & $\begin{array}{l}\text { Customer sacrifices are the overall monetary and non-monetary costs that the } \\
\text { consumer invests in giving to the supplier in order to complete a transaction. }\end{array}$ & Marketing \\
\hline Lacan & 2005 & $\begin{array}{l}\text { The sacrifice is destined the capture of the other as such in the network of } \\
\text { desire. }\end{array}$ & Psychology \\
\hline Mateus & 2008 & $\begin{array}{l}\text { Sacrifice is the self-denial of something under the perspective of achieving it } \\
\text { more intensely and increased. }\end{array}$ & Sociology \\
\hline Matear & 2014 & $\begin{array}{l}\text { Sacrifice is a transformational behavior that evokes a sense of meaningful } \\
\text { personal loss, and is performed for the benefit of the relationship in which the } \\
\text { act is embedded. }\end{array}$ & Marketing \\
\hline
\end{tabular}

Search: elaborated by the authors.

\section{Step 2: Generating Items and Validating Content}

The second step was characterized by the activities of item generation (CHURCHILL, 1979) and validation of face and content (COSTA, 20I I). For that, the reflective nature of the construct and the definition presented previously were considered. Based on an exploratory study operationalized through a theoretical study and a focus group (performing in July 2015) composed of market- ing and consumer behavior specialists, it was possible to list 19 items to compose the proposed scale. Then the items were submitted to the evaluation of nine marketing specialists (3 PhD and $6 \mathrm{PhD}$ students). For Churchill (1979), the use of focus groups can bring advantages at the item-generation stage and the use of specialists to evaluate the development of scaling items has been commonly used in marketing (e.g. ZAICHKOWSKY, 1985; BABIN; BURNS, 1998). 
The items in which six or more of the nine reviewers rated as representative of the construct were maintained for the next stage of scale development. This process resulted in II items, out of 19 originally submitted. Subsequently, the II items were sent for evaluation by two PhDs in marketing, which resulted in four rounds of evaluation, incorporation of suggestions, modification and new submission for evaluation. At the end of this process, 10 items remained that were considered fit to be included in the measurement instrument. The finds from literature were also considered to validate this step.

\section{Step 3: Decisions about responses}

In the process of deciding which scale of inquiry would be used for items, a 7-point type Likert scale was used, ranging from I (totally disagree) to 7 (totally agree). This type of scale is widely used in the social sciences (DEVELLIS, 2003) because it presents, among other advantages, psychometric consistency and easiness of the respondents to indicate their degree of agreement with the affirmative (COSTA, 20 I I).Also, respondents tend to have a good comprehension of this scale format.

\section{Step 4: Construction of the research instrument}

The construction of the instrument was characterized as the finalization of the decisions made in the content and face validation phases, and the choice of the verification scale. Therefore, a pre-test was applied with nine consumers, with different profiles of gender, age, profession and income, where difficulties were detected in the understanding of two questions, which were excluded from the questionnaire. Finally, the final instrument was composed of 8 items, as shown in Table 2.

In the elaboration of the instrument for the data collection phase, the questions were randomly distributed, with content (8 questions), socioeconomic (5 questions), and demographic (7 questions) items.

\section{Step 5: First sampling activity}

The purpose of this stage was to generate a first data collection that would enable exploratory tests to be performed, aiming at the purification of the measurement instrument (as demonstrated in step 6 below).

The first data collection was performed in August 2015 from an online questionnaire, whose link was disclosed through social networks and e-mail, and used as a product to measure the purchase of a smartphone. The decision to choose this product to compose the questionnaire

TABLE 2 - Items proposed for the scale of sacrifice to buy a good

\begin{tabular}{l|l}
\hline \multicolumn{1}{c|}{ Code } & \multicolumn{1}{c}{ Scale Items } \\
\hline SF1 & To buy $\quad$ I do not mind compromising my finances \\
\hline SF2 & To buy $\quad$ I am willing to save part of my income \\
\hline SF3 & To buy $\quad$ I give up activities that bring me pleasure \\
\hline SF4 & To buy I change my shopping routine to save money \\
\hline SF5 & When I buy $\quad$ As I strive to buy I am looking to demonstrate status with the groups I am a part of \\
\hline SF6 & To buy $\quad$ in a store, I do not mind wasting too much time \\
\hline SF7 & To buy
\end{tabular}

Search: elaborated by the authors. 
was mainly motivated by the wide use of cell phones by different consumer profiles. In addition, the smartphone is one of the most desired items for retail purchases, so that the number of cellphones in use in the world has gone from 7 billion according to International Telecommunications Union (ITU, 20I5). With regard to online data collection, Lefever, Dal and Matthíasdóttir (2007) state that the online data collection carries the potential of accessing a large and geographically distributed population. There are two main advantages in the process of data collection via the internet, the first is related to cost reduction (COUPER; ROWE, 1996; BETHLEHEM, 20I0) and the second refers to the speed of its driving (BETHLEHEM, 20 I0; GUNTER et al., 2002).

As an initial procedure of analysis, the adequacy of the data was verified in order to identify unanswered questions, errors and / or discrepant values. Therefore, three questionnaires with missing or discrepant values were excluded. At the end of this process, a total of 145 valid questionnaires were obtained. In the sample, 74 (5I.0\%) were women and 80 (55.2\%) were unmarried. Almost all of the respondents, I 44 (99.3\%) respondents have higher education level (incomplete, complete or postgraduate). The age varied from 19 to 60 years, with family income between $R$
$\$ 600,00$ and $R \$ 30,000.00$. Such sample composition indicated suitability in terms of heterogeneity, which ensured adequate and necessary conditions for carrying out the next step.

\section{Step 6: Scaling refinement procedures}

At this stage, the data was processed and analyzed aiming to proceed to the first sequence of refinement of the scale. Its operation consisted in analyzing the behavior of the measurement items eliminating those that did not present a bivariate correlation psychometric adequacy, internal consistency and factorial adequacy. In order to do so, the bivariate correlation matrix (Pearson) was extracted from the set of items, the results of which are shown in Table 3. The correlation matrix analysis showed that some measurements presented statistically null values ( $p<0.05)$. Considering the assumption that items should be reflective of the latent construct, it is understood from this analysis that items with a factorial load of less than 0.3 (items SF6, SF7 and SF8) should be candidates for scale elimination. Thus, it was decided that in the next phases of analysis these items would be eliminated.

As a form of appreciation and adjustment of the consistency of the measure and possible exclusion of items, two rounds of anal-

TABLE 3 - Correlation of items set

\begin{tabular}{c|c|c|c|c|c|c|c}
\hline Code & SF1 & SF2 & SF3 & SF4 & SF5 & SF6 & SF7 \\
\hline SF2 & 0,52 & & & & & & \\
\hline SF3 & 0,57 & 0,54 & & & & & \\
\hline SF4 & 0,53 & 0,44 & 0,59 & & & & \\
\hline SF5 & 0,39 & 0,38 & 0,42 & $\mathbf{0 , 2 9}$ & & & \\
\hline SF6 & $\mathbf{0 , 1 3}$ & $\mathbf{0 , 1 4}$ & $\mathbf{0 , 1 6}$ & $\mathbf{0 , 2 2}$ & $\mathbf{0 , 0 3}$ & & \\
\hline SF7 & $\mathbf{0 , 1 3}$ & $\mathbf{0 , 2 1}$ & 0,38 & $\mathbf{0 , 2 2}$ & 0,32 & $\mathbf{0 , 1 1}$ & \\
\hline SF8 & $\mathbf{0 , 1 8}$ & $\mathbf{0 , 0 8}$ & $\mathbf{0 , 1 5}$ & $\mathbf{0 , 1 4}$ & $\mathbf{0 , 2 3}$ & $\mathbf{0 , 1 9}$ & 0,36 \\
\hline
\end{tabular}

Search: elaborated by the authors.

92 R. Adm. FACES Journal Belo Horizonte v. 17 n. 3 p. 84-99 jul./set. 2018. ISSN 1984-6975 (online). ISSN 1517-8900 (Impressa) http://dx.doi.org/10.21714/1984-6975FACES2018V17N3ART5802 
ysis were performed: a) data adequacy test for factorial analysis (Kaiser-Meyer-Olkin test (KMO) and Bartlett's sphericity test); B) Exploratory Factor Analysis (EFA) and; C) reliability test (Cronbach's Alpha). At the end of this process, the best fit (without item SF5) presented the following results: Kaiser-Meyer-Olkin test of sampling adequacy $(\mathrm{KMO}=0.798)$ and Bartlett's sphericity $\left(\chi^{2}=|9|, 82 \mathrm{I}, \mathrm{df}=6, \mathrm{p}<0.00 \mathrm{I}\right)$, demonstrating the adequacy of the data for factorial analysis (HAIR JR., 2005).

In the extraction of factors, only one eigenvalue above I, as predicted was observed, with a variance extracted from $64.81 \%$, a value considered satisfactory. In the internal consistency verification procedure, a measure of the reliability of the scale, a Cronbach alpha value of 0.818 was obtained, which suggests that the set of items presents a good internal consistency.

The results of the factorial scores and commonalities of each variable are shown in the Table 4. In order to extract the factors, it was used the main components method (with number of factors defined by size eigenvalues greater than I) and orthogonal rotation by the varimax method. In the results of the factorial scores of variables and commonalities, it was possible to observe that all items presented high scores (above 0.7), a fact that indicates a good fit in the factorial structure.

In view of the set of analyzes carried out (correlation, exploratory factorial and
Cronbach's alpha), it was identified that after the elimination of some items, the final result signaled that the remaining items are consistent and adequate for measuring the financial sacrifice construct for purchase. However, Churchill (1979) suggests that this first purification process is not enough to consider the items as valid to measure the construct, so it is necessary to develop new field activity, as described below.

\section{Step 7:Additional fieldwork}

After consolidating the previous steps, the model used foresees the accomplishment of additional field works in order to carry out new tests with the scale and, if necessary, to perform a new cleaning purification of the items. In this sense, a new version of the scale was developed contemplating only the remaining items of the previous stages (SFI, SF2, SF3 and SF4), adding questions related to economic and social profile of the interviewees.

In search to have a sample of participant with adequate profile of consumers who carry out sacrifice to buy smartphones, the data collection was performed at natural settings (churches, schools, colleges and academies), and at the internet with a link available in social networks. The decision to use the internet too for data collection in this second round was justified by the significant index of online purchases of smartphone. The questionnaires were applied in the months of April, May and June of 2016.

TABLE 4 - Scores and commonalities

\begin{tabular}{l|l|c|c}
\hline Code & Scale Items & Scor. & Com. \\
\hline SF1 & To buy a smartphone, I do not mind compromising my finances & 0,813 & 0,661 \\
\hline SF2 & To buy a smartphone, I am willing to save part of my income & 0,769 & 0,592 \\
\hline SF3 & To buy a smartphone, I give up activities that bring me pleasure & 0,843 & 0,711 \\
\hline SF4 & To buy a smartphone, I change my shopping habits to save money & 0,793 & 0,628 \\
\hline
\end{tabular}

Search: elaborated by the authors. 
At the end of the data collection process, 282 questionnaires were obtained, 12 of which were considered invalid due to lack of data or discrepant values. Thus, the final sample consisted of 270 valid questionnaires with a profile composed of 143 (53\%) women, I 87 (69.3\%) singles and 62 $(23 \%)$ indicated having children.

Regarding the level of formal education, $8(3 \%)$ had a completed elementary education or an incomplete secondary school, 107 (39.6\%) had a completed high school or incomplete superior education, $63(23.3 \%)$ with a university degree or incomplete specialization and, 92 (34.1\%) postgraduate. Age ranged from 18 to 67 years, with a socioeconomic classification distributed as follows: 40 (14.8\%) belonging to class $A$, I5I (55.9\%) of classes BI and B2, 7I (26.3\%) of classes $\mathrm{Cl}$ and $\mathrm{C} 2$, and 8 (3\%) considered as belonging to classes $\mathrm{D} / \mathrm{E}$. In general, it can be said that the sample has heterogeneous characteris- tics suitable for the appropriate analyzes in this second sampling process.

\section{Step 8:Additional Scale Purification Procedures}

The objective of this step was to apply confirmatory factor analysis procedures to the new set of data (Table 5). For this step, a statisctical packaged well known in social sciences was used, since it allows the factorial extraction with an additional set of adjustment measures and hypothesis tests on the factorial scores. After verification of the interactions, it was decided to eliminate item SFI, as it presented a lower factor score and allowed the aggregate improvement in the adjustment measures. The final scale therefore included 3 items.

The results presented in Table 5 indicate a good adequacy of the scores (all above 0.59 and statistically non-zero). Adjustment measures are within the limits suggested in the literature, except for the $\mathrm{P}$-value of the chi-square test and RMSEA.

TABLE 5 - Confirmatory Factorial Analysis

\begin{tabular}{|c|c|c|c|}
\hline \multicolumn{2}{|l|}{ VARIABLES } & SCORES & $C R^{*}$ \\
\hline \multicolumn{4}{|c|}{ Panel 1 - Factorial Items and Scores } \\
\hline \multicolumn{2}{|l|}{ SF2 - To buy a smartphone, I am willing to save part of my income } & 0,726 & 7,390 \\
\hline \multicolumn{2}{|l|}{ SF3 - To buy a smartphone, I give up activities that bring me pleasure } & 0,592 & 7,270 \\
\hline \multicolumn{2}{|c|}{ SF4 - To buy a smartphone, I change my shopping routine to save money } & 0,740 & ** \\
\hline \multicolumn{4}{|c|}{ Panel 2 - Adjustment Measures } \\
\hline Adjustment Measure & Observed & \multicolumn{2}{|c|}{ Fitness requirement } \\
\hline Chi-square (x2) & 4,312 & \multicolumn{2}{|c|}{-} \\
\hline Degrees of Freedom (glm) & 1 & \multicolumn{2}{|c|}{-} \\
\hline Reason x2/glm & 4,312 & \multicolumn{2}{|c|}{$<5,000$} \\
\hline p-value & 0,038 & \multicolumn{2}{|c|}{$>0,050$} \\
\hline Quality adjustment index - GFI & 0,990 & \multicolumn{2}{|c|}{$>0.900$} \\
\hline Comparative adjustment index $-\mathrm{CFI}$ & 0,980 & \multicolumn{2}{|c|}{$>0.900$} \\
\hline Tucker-Lewis Index - TLI & 0,939 & \multicolumn{2}{|c|}{$>0.900$} \\
\hline Regulated adjustment index - NFI & 0,974 & \multicolumn{2}{|c|}{$>0.900$} \\
\hline Root Mean Square Error of Approximation - RMSEA & 0,111 & \multicolumn{2}{|c|}{$<0,080$} \\
\hline Variance explained & $64,60 \%$ & \multicolumn{2}{|c|}{$>50 \%$} \\
\hline
\end{tabular}

Note: * Significance at $p<0.001$; ${ }^{* *}$ Item with score set to 1.

Search: elaborated by the authors.

94 R. Adm. FACES Journal Belo Horizonte v. 17 n. 3 p. 84-99 jul./set. 2018. ISSN 1984-6975 (online). ISSN 1517-8900 (Impressa) http://dx.doi.org/10.21714/1984-6975FACES2018V17N3ART5802 
According to Costa (20II), in the case of $\mathrm{p}$-value, the presented result is characterized as common in works with relatively large samples, which motivates the use of other measures. For RMSEA, Weston and Gore (2006) argue that sample size and complexity influence the appropriate cutoff values. In this sense, cutting criteria can result in incorrect rejection of acceptable models when sample sizes are smaller than $\mathrm{n}=500$ and when models are not complex, as in the case of this research. Thus, it is important to check the set of indicators for a better evaluation. In these terms, it is understood that the results indicate a good fit of the sample of items to measure the latent construct.

As noted by Dodds, Monroe and Grewal (199I), and Lapierre (2000), sacrifice in consumption involves both monetary and non-monetary aspects. In the scale, two items (SF2 and SF4) are directly linked to the financial aspect in the act of sacrificing. In turn, item SF3 brings the renunciation aspect also reinforced by Bataille (1989) in conceiving sacrifice as cost. This element intertwines the financial element, reinforcing the transcendental aspect related to the pleasure already described by Simmel (1990).

\section{Step 9: Validity and reliability analysis of the final scale}

This step is considered one of the most important, since it aims to confirm the characteristics of validity and reliability. Convergent and discriminant validities are usually presented. With regard to the convergent validity (points out the adequacy of the set of items in terms of repeated measures of the construct), the critical ratio (CR) values of the statistical output were adopted as reference. In this sense, it was observed that all values were statistically non-zero $(p<0.05)$, which indicates the existence of a variation of the items coming from the latent construct. Confirmation of this verification indicates that evidence of convergent validity has been achieved (MOUTINHO; HUARNG, 20I2).

In relation to the discriminant validity (which indicates the degree to which two measures are different), it was not possible to carry out such an evaluation because the construct was measured in a unidimensional manner, in accordance with the proposed objectives.

Finally, the reliability analysis was done by internal consistency analysis, using the Cronbach alpha coefficient. The final value of the three items was 0.726 , which indicates a good and accepted internal consistency in the set of items.

\section{Step 10: Developing standards and re- commendations}

This last stage consists in the development of recommendations for scale application. It is considered that although the scale has been applied in the purchase of a specific good, it is possible to use it to verify the sacrifice for the purchase of different products. In the instrument, the recommendation is for items to be randomly distributed. It is also suggested the use of a I0-point verification scale, since these always present good results (MATELL; JACOBY, 197I).

\section{FINAL CONSIDERATIONS}

The proposal developed in this study was to design a scale for measuring financial sacrifice for the purchase of a product. The results presented here indicate that the objective of the research was sat- 
isfactorily achieved, with the development of a metric based on three items (affirmations), using a Likert-type verification scale. The result, obtained by means of analyzes and refinements, is presented in Table 6, set out below.

In general terms, the items (statements) presented in Table 6 are linked to the negative feeling of loss due to the financial difficulty. The first statement refers to the effort to sacrifice the benefits of a present purchase in the light of a future acquisition to obtain a greater benefit. Similarly, the second item of the scale seeks to measure the importance that the individual attributes to the desired product. We assume that the greater this importance, the greater the tendency for the financial sacrifice to be realized. Finally, the third affirmation seeks to measure the predisposition to change the buying routine: the greater the willingness to change this routine, the greater will be the tendency of the individual to realize the financial sacrifice. The three items of the scale goes along with the one presented by Gomes (2018), when affirming that the sacrifice for purchases is a willingness to give up something that is valued (monetary or otherwise) to obtain some benefit (emotional and / or material) of greater importance.

The results of this paper have practical implications for retail, insofar as the scale can be used to measure the sacri- fice performance by clients, thus facilitating the development of actions that may reduce the possible perceived negative effects of the sacrifice act and reinforce the positive ones. In the current economic scenario, with scarce resources, wants and needs of consumers are often translated into a sacrifice to buy, which, among other things, impairs the buyer's income, producing reduction or elimination of consumption of other items: it is a trade-off where cognitive and emotional aspects are present.

It can be considered that when it occurs to the extreme, such aspects produce negative factors for the consumer, their families and even for the economy. Thus, the monitoring of sacrifice for purchase becomes an important element, since there is a strong appeal of consumption, generating the need for an instrument, rigorously developed and validated, as presented in this study.

In academic terms, the proposition of a scale for measuring sacrifice for the purchase of products already constitutes a relevant contribution, since it was not identified in the literature an instrument with such characteristics to measure an act so common in current times. Developing a measurement method for the purchase sacrifice also contributes to the encouragement of studies focused on the central construct of this paper, helping to strengthen and expand the applicability of sacrifice in different perspectives and spaces of consumption.

TABLE 6 - Proposed scale for financial sacrifice for purchase of a product

\begin{tabular}{ll}
\hline To buy & I am willing to save part of my income \\
\hline To buy & I give up activities that bring me pleasure \\
\hline To buy & I I change my shopping routine to save money \\
\hline
\end{tabular}

Search: elaborated by the authors.

96 R. Adm. FACES Journal Belo Horizonte v. 17 n. 3 p. 84-99 jul./set. 2018. ISSN 1984-6975 (online). ISSN 1517-8900 (Impressa) http://dx.doi.org/10.21714/1984-6975FACES2018V17N3ART5802 
JAIRO DE PONTES GOMES, SALOMÃO ALENCAR DE FARIAS, MARIANNY JESSICA DE BRITO SILVA, FRANCISCO VICENTE SALES MELO, POLYANA DE LOURDES SARAIVA DO NASCIMENTO

Even with possible contributions presented on this article, some limitations were identified during the study. In particular, the fact that the proposed scale has been tested with a single product.
Although this is not a major problem, it is recommended that academic efforts be undertaken to validate the scale involving goods, services and consumption experiences. 


\section{REFERÊNCIAS}

BABIN, L. A.; BURNS, A. C. A modified scale for the measurement of communication-evoked mental imagery. Psychology \& Marketing, v. I 5, n. 3, p. 26I-278, 1998.

BADJE, D. To possess and to be possessed: the sacred facet of gift giving. European Advances in Consumer Research, v. 7, p. |76-|8I, 2005.

BATAILLE, G. Theory of Religion. New York: Zone, 1989.

BELK, R.W.; TUMBAT, G. The Cult of Macintosh. Consumption Markets \& Culture, v. 8 ,n.3, p. 205217, 2005.

BELK, R. W.; WALLENDORF, M.; SHERRY, J. F. The sacred and the profane in consumer behavior: Theodicy on the odyssey. Journal of consumer research, v. 16, n. I, p. I-38, 1989.

BETHLEHEM, J. Selection bias in web surveys. International Statistical Review, v. 78, n. 2, p. I6I-I88, 2010. BUBBIO, D. G. Kant's sacrificial turns. Int J Philos Relig, v. 73, n. 2, p. 97-II5, 2013.

CARUANA, A.; MONEY, A. H.; BERTHON, P. R. Service quality and satisfaction-the moderating role of value. European Journal of marketing, v. 34, n. I //12, p. |338-|353, 2000.

CHANG, C.J. Price or quality? The influence of fluency on the dual role of price. Marketing Letters, v. 24, n. 4, p. 369-380, 2013.

CHURCHILL, G. A. J. A paradigm for developing better measures of marketing constructs. Journal of Marketing Research, v. 16, n. I, p. 64-73, 1979.

COSTA, F. J. Mensuração e desenvolvimento de escalas: aplicações em administração. Rio de Janeiro: Ciência Moderna, 20 I I. COUPER, M. P.; ROWE, B. Evaluation of a computer-assisted self-interview component in a computer-assisted personal interview survey. The Public Opinion Quarterly, v. 60, n. I, p. 89-105, 1996.

CURRÁS, R.; GALLARZA, M. G.; SERVERA, D.; FAYOS, T.; ARTEAGA, F. The Consumer Value Trade-Off and The International Experience: Benefits And Costs Of Being An Erasmus Student. INTED20 I5 Proceedings, p. 4008-40I7, 2015. DEVELLIS, R. F. Scale Development: Theory and Applications. 2. ed. Thousand Oaks: SAGE Publications, 2003.

DODDS, W. B.; MONROE, K. B. The Effect of Brand and Price Information on Subjective Product Evaluations. In Hirshman E. and Holbrook M., (eds.) Advances in Consumer Research 12, Provo, Utah: Association for Consumer Research: p. 85-90, 1985.

DODDS,W.B.; MONROE, K. B.; GREWAL, D. Effects of price, brand, and store information on buyers' product evaluations. Journal of marketing research, v. 28, n. 3 , p. 307-319, 1991.

ENGEL, J. F.; BLACKWELL, R. D.; MINIARD, P. W. Consumer behavior. Hindsale: The Dryden Press, 1995.

EVANS-PRITCHARD, E. E. Nuer religion. Oxford: Clarendon Press, 1956. FLINT, D. J.;WOODRUFF, R. B.; GARDIAL, S. F. Customer value change in industrial marketing relationships:A call for new strategies and research. Industrial Marketing Management, v. 26, n. 2, p. 163175, 1997.

FONG, L.; KIAN,T. P.; FERN,Y. S.;VINCENT, W. Monetary and Image Influences on the Purchase Decision of Private Label Products in Malaysia. Journal of Advanced
Management Science, v. 3, n. 4, p. 3।2-318, 2015.

FREUD, S. Totem e tabu e outros trabalhos (19/3/19/4). (Ó. C. Muniz, Trans.) Imago (Vol. XIII). Rio de Janeiro: Imago, 1996.

GIRARD, R. Violence and the Sacred. London:Athlone, 1995.

GUNTER, B.; NICHOLAS, D.; HUNTINGTON, P.; WILLIAMS, P. Online versus offline research: implications for evaluating digital media. Aslib Proceedings, v. 54, n. 4, p. 229-239, 2002.

HAIR JR, J. F. Análise multivariada de dados (5th ed.). Porto Alegre: Bookman, 2005.

HUBERT, H.; MAUSS, M. Essai sur la nature et la fonction du sacrifice. L'Année Sociologique (/896//897-1924//925), v. 2, p. 29-138, 1897.

ITU, International Telecommunications Union. Internet well on way to 3 billion users, UN telecom agency reports. Available in : http://www.un.org/ apps/news/story.asp?NewsID=47729\#.WYTGhljyvIU. Access: August 4, 2017.

LACAN, J. O Seminário, livro I0: a angústia. (V. Ribeiro, Trans.). Rio de Janeiro: Jorge Zahar, 2005.

LAPIERRE, J. Customer-perceived value in industrial contexts. Journal of Business \& Industrial Marketing, v. I5, n. 2/3, p. I22-I45, 2000.

LEFEVER, S.; DAL, M.; MATTHÍASDÓTTIR, Á. Online data collection in academic research: Advantages and limitations. British Journal of Educational Technology, v. 38, n. 4, p. 574-582, 2007.

LILJANDER, V.; STRANDVIK, T. The nature of consumer relationships in Services. In: Swartz, Teresa A, David E. Bowen and Stephen W. Brown (eds.). Advances in Ser-

R. Adm. FACES Journal Belo Horizonte v. 17 n. 3 p. 84-99 jul./set. 2018. ISSN 1984-6975 (online). ISSN 1517-8900 (Impressa)

http://dx.doi.org/10.21714/1984-6975FACES2018V17N3ART5802 
vices Marketing and Management (pp. I4I-I67). London: JAI Press Inc, 1995.

LIN, C.,WU, P.; CHUANG, S.; KAO, D. T.Price as a quality or sacrifice cue : Role of goal orientation. Asian Journal of Social Psychology, v. I0, n. 3, p. I79-187, 2007.

MATEAR, M. A. The Role and Nature of Willingness to Sacrifice in Marketing Relationships. Kingston: Queen's University, 2014.

MATELL, M. S.; JACOBY, J. Is There an Optimal Number of Alternatives for Likert Scale Items? Study I: Reliability and Validity. Educational and Psychological Measurement, v. 3I, n. 3, p. 657-674, I97I.

MATEUS, S. A identidade como Sacrifício. In VI Congresso Português de Sociologia - Lisboa, 2008.

MONROE, K.B. Pricing: Making Profitable Decisions. New York: McGraw-Hill, 1990.

MOUTINHO, L.; HUARNG, K-H. Quantitative Modelling in Marketing and Management. London:World Scientific, 2012.

PINE, B. J.; GILMORE, J. H. Satisfaction, sacrifice, surprise: three small steps create one giant leap into the experience economy. Strat- egy \& Leadership, v. 28, n. I, p. 18-23, 2000.

SHILLING, C.; MELLOR, P. A. (20I3). Making things sacred: re-theorizing the nature and function of sacrifice in modernity. Journal of Classical Sociology, v. I3, n. 3, p. 319-337, 2013.

SIMMEL, G. The Philosophy of Money. London: Routledge, 1990. SMITH, W. R. Lectures on the Religion of the Semites English. London:Adam and Charles Black, 1984.

SUMAEDI, S.; BAKTI, I. G. M.Y.;YARMEN, M. The empirical study of public transport passengers' behavioral intentions: the roles of service quality, perceived sacrifice, perceived value, and satisfaction (case study: paratransit passengers in Jakarta, Indonesia). International Journal for Traffic \& Transport Engineering, v. 2, n. I, 2012.

SYKERS, A. A. An Essay on the Nature, Design, and Origin, of Sacrifices. London: J. and P. Knapton, 1748.

TEAS, R. K.;AGARWAL, S. The effects of extrinsic product cues on consumers' perceptions of quality, sacrifice, and value. Journal of the Academy of marketing
Science, v. 28 , n. 2, p. 278-290, 2000.

TSENG, C. H. The effect of price discounts on green consumerism behavioral intentions. Journal of Consumer Behavior, v. 15, n. 4, 325-334, 2016.

VAN LANGE, P. A. M.; DRIGOTAS, S. M.; RUSBULT, C. E.; WITCHER, B. S.; ARRIAGA, X. B.; COX, C. L. Willingness to sacrifice in close relationships. Journal of Personality and Social Psychology, v. 72, n. 6, p. 1373-1395, 1997.

WESTON, R.; GORE, J. P. A. A Brief Guide to Structural Equation Modeling. The Counseling Psychologist, v. 34, n. 5, p. 7I9-75।, 2006.

WOODALL, T. Conceptualising "Value for the Customer": An Attributional, Structural and Dispositional Analysis. Academy of Marketing Science Review, v. I2, n. 5, p. I-42, 2003.

ZAICHKOWSKY, J. L. Measuring the Involvement Construct. Journal of Consumer Research, v. 12, n. 3, p. 34I-352, 1985.

ZEITHAML, V. A. Consumer perceptions of price, quality, and value: a means-end model and synthesis of evidence. The Journal of Marketing, v. 52, n. 3, p. 2-22, 1988. 